\title{
The Determinants of Acquirer Returns in the Turkish Stock Market
}

\author{
Ebru Reis* \\ Istanbul Bilgi University
}

\begin{abstract}
This study examines the stock market reaction and the determinants of this reaction to the announcements of company acquisitions for acquiring firms in the Turkish Stock Market during the period 1994-2013. Standard event study methodology is used to measure abnormal returns of acquiring companies during the announcement period. Contrary to the findings in the developed markets, the acquirers in Turkey earn a significant positive cumulative abnormal return of $2.27 \%$ during an 11 -day announcement period. Acquirer returns are higher in mergers compared to acquisitions, and in same business acquisitions compared to unrelated acquisitions. However, no statistically significant evidence is observed for the effect of a target firm's country of origin (domestic vs cross-border), or public status on the acquirer announcement period returns.
\end{abstract}

Keywords: mergers and acquisitions, acquirer returns.

JEL Classification: G31; G34

\section{Türkiye Pay Piyasasındaki Şirket Birleşmelerinde Satın Alan Şirketlerin Pay Getirilerindeki Belirleyici Etmenler}

\section{Özet}

Bu çalışma, 1994-2013 yılları arasında Türkiye pay piyasasındaki şirket birleşme ve satın alma haberlerinin satın alan şirket hisse senedi üzerindeki etkisini ve bu etkinin belirleyici etmenlerini incelemiştir. Satın alan şirketlerin anormal pay getirileri standart olay çalışması yöntemi kullanılarak hesaplanmıştır. Gelişmiş ülke piyasalarında yapılan çalışmaların aksine, Türkiye'de satın alan şirketlerin duyuru günü merkezli 11 günlük zaman aralığında yüzde 2.27 oranında kümülatif anormal getiri elde ettiği ortaya konmuştur. Satın alan şirketlerin pay getirileri, şirket evliliklerinde kısmi satın almalara kıyasla ve benzer sektör birleşmelerinde farklı sektör birleşmelerine kıyasla daha yüksektir. Bununla beraber, hedef şirketin orijin ülkesinin (yerli veya uluslararası) ve halka açıklık durumunun satın alan şirketin pay getirileri üzerinde istatiksel olarak anlamlı bir etkisi gözlemlenmemiştir.

Anahtar Kelimeler: Şirket birleşmeleri, Satın alan şirket getirileri

JEL Sinıflaması: G31; G34 * Ebru Reis is an Assistant Professor in the Department of Business Administration at İstanbul Bilgi University, Santral Istanbul
Campus, Kazım Karabekir Cad.No:2/13, 34060, Eyüp, Istanbul, Turkey. E-mail: ebru.reis@bilgi.edu.tr 
7 he stock price reaction to acquirers and targets in company acquisitions has been thoroughly investigated in the developed markets in the last three decades largely due to the high number of merger and acquisition (M\&A) activities and the availability of data in these countries. The rapid development of emerging markets particularly in the last decade resulted in a rapidly growing M\&A market in these countries. ${ }^{[1]}$ However, since the dynamics of the financial markets in the developing markets, such as the market for corporate control, corporate governance, and the transparency of information are quite different from their counterparts in the developed markets, there is a growing research on the mergers and acquisitions in the emerging markets as well as cross-border acquisitions in the developed markets. As the product and capital markets become more integrated, it remains a question to be explored further if and how the wealth effects of acquisitions in the emerging markets such as in Turkey differ from those in the developed markets.

In this paper, I investigate merger and acquisition announcement returns for Turkish acquirers and analyze determinants of these returns using several deal characteristics. The consensus findings in the literature show that the target firms gain positive and significant announcement returns in the range of $10 \%-30 \%$ in the developed markets. However, the evidence is mixed for the acquiring firms. Researchers document negative, zero and positive abnormal returns for the acquirers ranging from $-1.5 \%$ to $2 \% \cdot{ }^{[2]} \mathrm{In}$ this study, I find that the Turkish acquirers earn a significant positive $2.27 \%$ on average around the announcement date and this positive gain is enhanced if the target and acquirer firms are in the same business or if the transaction is a merger rather than an acquisition. I do not find any evidence that cross-border transactions or the acquisition of a public target rather than a private firm have any statistically significant effect on the announcement returns for the acquirer.

Parallel to the increasing volume of merger and acquisition activities in Turkey especially after the financial crisis of 2001, the number of studies investigating M\&A related issues in Turkey is also flourishing in the last decade. However, these studies primarily focus on the overall M\&A activity (Akdoğu, 2011, 2012; Erdoğan, 2012), the financial performance of acquirer and target firms before and after the acquisition (Mandac1, 2005; Akben-Selçuk, 2008), mergers in the banking sector (Mumcu and Zenginobuz, 2002; Çukur and Eryiğit, 2006) and short-term wealth effects of acquisition announcement on the target firms (Mandac1, 2004; Hekimoğlu and Tanyeri, 2011; and Arslan and Şimşir, 2015). The stock market reaction to the announcement of acquisitions for the acquirers in Turkey remains a neglected area in the literature. To my knowledge, the one directly relevant study to the present study is by Oelger and Schiereck (2011). They find that in international acquisitions Turkish acquirers earn a significant $5.16 \%$, whereas announcement returns are indistinguishable from zero if the target is a domestic firm during 1992-2010. Their sample is comprised of 112 observations including all full

\footnotetext{
[1] The total number of mergers and acquisitions in the period 1994-2003 was 53, whereas this number rose to 235 in the period 2004-2013 in the next decade in Turkey (Source: Securities Data Corporation).

[2] See Bruner (2004) for a thorough review of findings in the literature.
} 
and partial acquisitions. Contrary to their finding, the present study documents evidence that the wealth gains of acquiring firms are not statistically different for the cross-border and domestic acquisitions in Turkey, and acquirers earn on average a $2.13 \%$ in domestic acquisitions if the controlling share of the target is acquired.

The emphasis in this paper is on the acquirer returns in the Turkish M\&A market. However, it is worthwhile to mention a few studies that conduct a similar analysis for the Turkish targets in recent works. Mandacı (2004), Hekimoğlu and Tanyeri (2011), and Arslan and Şimşir (2015) document that target firms earn abnormal returns in the range of $8.6 \%-9.6 \%$ on average around the announcement date of the acquisitions. These findings also provide support to the argument that the short-term wealth effects of acquisitions in Turkey for both targets and acquirers differ from their counterparts in the developed markets on average.

The remainder of the paper is organized as follows. The next section reviews the literature and it is followed by a description of the sample and the methodology. The paper then continues with the results of univariate and multivariate analyses followed by the conclusion in the last section.

\section{Magnitude and Sources of Acquirer Returns in the Literature}

\section{Magnitude and Direction of Acquirer Abnormal Returns}

The research on the stock price reaction of merger and acquisition announcements for targets is vast and unanimous documenting large premiums for target shareholders. However, the evidence on the returns to acquiring companies is mixed. ${ }^{[3]}$ While some research finds small positive returns for the acquiring company around the announcement date ranging from $0.7 \%$ to $1.8 \%$ (see Fueller et al., 2002; Moeller et al., 2004, 2005; Georgen and Renneboog, 2004; Bradley and Sundaram, 2006), other studies report significant negative abnormal returns for the acquiring company ranging from $-1.4 \%$ to $-0.48 \%$. (see Sudarsanam and Mahate, 2003; Ang and Cheng, 2006; Betton, Eckbo and Thornburn, 2009). In addition to these, Jensen and Ruback (1983), Lang et al. (1989), Moeller et al. (2007) find that the announcement date returns are not distinguishable from zero for the bidder company. In a comprehensive study including 67,256 deals, Netter et al. (2011) report that the average acquisition represents a statistically significant $1.1 \%$ gain to the acquirer.

In the emerging markets, Bhagat et al. (2011) report an average of $2.17 \%$ announcement returns for the acquiring firms in cross-border acquisitions. Their study includes the following countries (note that Turkey is excluded): Brazil, China, India, Malaysia, Mexico, Philippines, Russia, and South Africa. Ma et al. (2009) find similar results in Asian markets over the 2000-2005 period. However, Aybar and F1çıcı (2009) find that on average cross-border expansions of multinational companies in emerging markets (predominantly in Latin America and Asia) through acquisitions do not create value. In

[3] For a full literature review of short term wealth effects of takeovers for target and acquiring companies see Bruner (2004), Martynova and Renneboog (2008) and Eckbo (2009). 
single country studies, Kohli and Mann (2012) find positive and significant abnormal returns $(2.07 \%)$ for the cross-border acquisitions but insignificant abnormal returns for domestic acquisitions in India. Chi et al. (2011) report positive and significant returns $(0.27 \%)$ in China.

\section{Cross-border vs Domestic Acquisitions}

The literature proposes competing hypotheses for why a cross-border acquisition may affect the returns of the acquirer firm. ${ }^{[4]}$ Cross-border acquisitions may increase the opportunity set and diversification of the acquirer, lower costs, and therefore may increase the synergy gains of the acquirer. On the other hand, increased competition in the market for corporate control and increased hubris and agency problems may lead to lower acquirer returns.

Several studies document that the overall effect of cross-border acquisitions on the acquirer stock price is significantly negative in the developed markets (see e.g. Moeller and Schlingemann, 2005; Chatterjee and Aw, 2000; Eckbo and Thorburn, 2000; Conn et al., 2005; Martynova and Renneboog, 2008). Dos Santos et al. (2008) examine the diversification discount around cross-border acquisitions and find that diversifying cross-border acquisitions destroy value. However, Chari et al. (2009) find that although developed market acquirers do not observe a significant announcement return when acquiring a target in a developed countries, they earn a positive and significant $1.16 \%$ on average when acquiring a target in the emerging markets. In addition, Seth et al. (2002) show that in the value-increasing cross-border acquisitions, the source of the gains is mainly reverse internalization of valuable intangible asset, whereas in value-destroying cross-border acquisitions the source of value destruction is consistent with risk reduction. In summary, the empirical evidence for the effect of cross-border acquisitions on acquirer announcement returns is mixed.

\section{Public vs Private Targets}

The acquirer returns when buying public versus private targets are also examined in the literature. It is hypothesized that since acquirers receive a better price when buying a private firm compared to buying public ones due, to the liquidity effect and that the acquirer managers are less likely to make decisions with hubris in privately held negotiations, acquirer returns are higher when the target firm is private. ${ }^{[5]}$ Chang (1998), Fuller et al., (2002), Faccio et al (2006) and Bradley and Sundaram (2006) document that the acquirers have significantly negative announcement returns when buying a public firm; however they have significantly positive returns when buying a private firm in the US market. Conn et al., (2005) confirmed this finding in a study conducted for UK acquirers during 1984-1998 and Capron and Shen (2007) find similar results for a sample of multinational acquirers including U.S. acquirers. However, although Chang (1998) Yüce and $\mathrm{Ng}$ (2005) also find that there are significant and positive cumulative

\footnotetext{
${ }^{[4]}$ For a detailed discussion of theoretical foundations of cross-border acquisitions see Shimizu et al. (2004).

${ }^{[5]}$ For a detailed discussion of these hypotheses see Fuller, Netter and Stegemoller (2002).
} 
abnormal returns to acquirers buying private firms with stock rather than public ones, they show that this difference disappears for cash deals.

\section{Same Business vs Unrelated Industry Acquisitions}

Industry relatedness is one of the most commonly used determinants of acquirer returns. Increased productive efficiency is suggested as an explanation for the positive relationship between industry relatedness and acquirer bidder returns. In the case of horizontal acquisitions, where the bidder and the target are in the same line of business, three basic motivations for horizontal acquisitions are productive efficiency, the increased monopolistic collusion in the industry and increased buyer power. ${ }^{[6]}$ The empirical evidence seems to support these arguments. Travlos (1987), Asquith et al. (1987) and Moeller and Schlingemann (2005) find a positive relationship between the business and acquirer returns around the announcement date. However, Fuller et al. (2002), Goergen and Renneboog (2004), Faccio et al. (2006) find no significant relationship between industry relatedness and acquirer returns.

\section{Mergers vs Tender Offers}

In the literature the mode of the acquisition is also shown to be a factor as a source of wealth gains for the acquiring company. Jensen and Ruback (1983), Datta et al. (2001) document evidence that acquirers earn more in tender offers than mergers around the announcement date. In the long-run, Aggrawal et al. (1992) and Loghran and Vijh (1997) also find that acquirers in tender offers outperform acquirers in mergers over a five-year period after the acquisition.

\section{Data Sample and Methodology}

\section{Sample}

The M\&A sample for this study is obtained from Thompson Reuter's Securities Data Corporation (SDC) database. The sample covers the period 1994 to 2013. To be included in the study sample, I require the following six points: i) The transaction is listed as completed with an announcement date in the sample period; ii) the acquirer firm is a publicly traded company on the Turkish Stock Exchange (Borsa Istanbul); iii) the acquiring firm is a non-financial firm; iv) the transaction is identified as a "merger," "acquisition of majority interest" using SDC; v) the acquirer does not own more than $20 \%$ of the target firm prior to the event date and owns at least $50 \%$ after the event date. $^{[7]}$ This sample consists of 110 successful acquisitions. Finally, vi) the acquirer firms have available stock return data around the takeover announcement date. This leads to a final sample of 106 acquisitions. The stock price and market capitalization of firms are obtained from Istanbul Borsa.

${ }^{[6]}$ For a detailed discussion of these hypotheses see Fee and Thomas (2004) and Shahrur (2005).

[7] By limiting the sample for the acquirer's ownership in the target company before and after the acquisition, the study focuses only on acquisitions that are likely to have a noticable impact on the market valuation of the acquiring company. 
The deal-specific characteristics and the firms' industries are obtained from Thomson Reuter's database. The variables I consider are commonly used in the analyses of acquirer returns in the literature. These variables are whether the acquirer's and target's businesses are in the same industry category as defined by SDC (Bradley et al., 1988); whether the acquisition is cross-border; whether the target firm is public, private or subsidiary of the acquirer firm; and the market value of the acquirer firms as measured one day prior to the event window. If both the target and the acquirer firms are defined in the same industry by SDC's database, the acquisition is defined as a same business acquisition; all others are defined as unrelated business acquisitions. If it is the acquirer's first deal in the sample period it is defined as the first deal; the subsequent deals by the same acquirer are defined as experienced deals.

\section{Sample Description}

Panel A of Table 1 reports data on acquisition characteristics. In the sample of 110 successful acquisitions, there are $72(66 \%)$ mergers and $38(34 \%)$ acquisitions. There are $13(12 \%)$ public targets, and $54(49 \%)$ private targets. More than one-third of the sample (38\%) comes from acquisition of subsidiaries and there is one government company as a target company in the sample. Consistent with earlier studies there are only $13(12 \%)$ cross-border acquisitions and the remaining 97 (88\%) targets are Turkish companies.

Table 1

\section{Sample Description}

Panel A: Deal Characteristics

\begin{tabular}{|c|c|c|c|c|c|}
\hline \multirow[t]{3}{*}{ Acquisition Form } & \multirow{3}{*}{$\begin{array}{l}\mathrm{N} \\
110\end{array}$} & \multicolumn{4}{|c|}{$\begin{array}{l}\text { Acquisition of } \\
\text { Majority Interest } \quad \text { Merger }\end{array}$} \\
\hline & & 72 & 38 & & \\
\hline & & $66 \%$ & $35 \%$ & & \\
\hline \multirow[t]{3}{*}{ Target Public Status } & & Public & Private & Subsidiary & Government \\
\hline & 110 & 13 & 54 & 42 & 1 \\
\hline & & $12 \%$ & $49 \%$ & $38 \%$ & $1 \%$ \\
\hline \multirow[t]{3}{*}{ Target's Nation } & & Domestic & Cross-Border & & \\
\hline & 110 & 97 & 13 & & \\
\hline & & $88 \%$ & $12 \%$ & & \\
\hline \multirow[t]{3}{*}{ Related Business } & & Same business & Unrelated & & \\
\hline & 110 & 45 & 65 & & \\
\hline & & $41 \%$ & $59 \%$ & & \\
\hline \multirow[t]{3}{*}{ Acquisition Experience } & & Experienced & First deal & & \\
\hline & 110 & 38 & 72 & & \\
\hline & & $35 \%$ & $65 \%$ & & \\
\hline
\end{tabular}


Table 1- continued

Panel B: Distribution of industries in the sample

\begin{tabular}{|c|c|c|c|c|}
\hline Industry & $\begin{array}{c}\text { Acquirer } \\
\text { No. of } \\
\text { Obs. }\end{array}$ & $\begin{array}{c}\% \text { of } \\
\text { sample }\end{array}$ & $\begin{array}{c}\text { Target } \\
\text { No of } \\
\text { Obs. }\end{array}$ & $\begin{array}{c}\% \text { of } \\
\text { sample }\end{array}$ \\
\hline Aerospace \& Defense & 0 & 0.00 & 1 & 0.91 \\
\hline Agriculture \& Livestock & 1 & 0.91 & 1 & 0.91 \\
\hline Automobiles \& Components & 2 & 1.82 & 2 & 1.82 \\
\hline Banks/Insurance & 0 & 0.00 & 6 & 5.45 \\
\hline Building/Construction & 7 & 6.36 & 1 & 0.91 \\
\hline Chemicals & 2 & 1.82 & 1 & 0.91 \\
\hline Computers \& Electronics Retailing & 2 & 1.82 & 1 & 0.91 \\
\hline Computers \& Peripherals & 1 & 0.91 & 0 & 0.00 \\
\hline Construction Materials & 7 & 6.36 & 8 & 7.27 \\
\hline Containers \& Packaging & 2 & 1.82 & 0 & 0.00 \\
\hline Discount and Department Store Retailing & 1 & 0.91 & 1 & 0.91 \\
\hline Electronics & 2 & 1.82 & 3 & 2.73 \\
\hline Food \& Beverage Retailing & 3 & 2.73 & 3 & 2.73 \\
\hline Food and Beverage & 8 & 7.27 & 7 & 6.36 \\
\hline Healthcare equipment & 0 & 0.00 & 1 & 0.91 \\
\hline Hospitals & 4 & 3.64 & 3 & 2.73 \\
\hline Hotels and Lodging & 1 & 0.91 & 2 & 1.82 \\
\hline Household \& Personal Products & 3 & 2.73 & 4 & 3.64 \\
\hline IT Consulting \& Services & 0 & 0.00 & 3 & 2.73 \\
\hline Metals \& Mining & 5 & 4.55 & 5 & 4.55 \\
\hline Motion Pictures / Audio Visual & 1 & 0.91 & 2 & 1.82 \\
\hline Oil \& Gas & 6 & 5.45 & 3 & 2.73 \\
\hline Other Retailing & 0 & 0.00 & 2 & 1.82 \\
\hline Paper \& Forest Products & 3 & 2.73 & 1 & 0.91 \\
\hline Pharmaceuticals & 1 & 0.91 & 2 & 1.82 \\
\hline Power & 11 & 10.00 & 18 & 16.36 \\
\hline Publishing & 4 & 3.64 & 2 & 1.82 \\
\hline REITs & 5 & 4.55 & 1 & 0.91 \\
\hline Recreation \& Leisure & 1 & 0.91 & 3 & 2.73 \\
\hline Software & 3 & 2.73 & 4 & 3.64 \\
\hline Telecommunications Equipment & 1 & 0.91 & 0 & 0.00 \\
\hline Telecommunications Services & 1 & 0.91 & 3 & 2.73 \\
\hline Textiles \& Apparel & 14 & 12.73 & 8 & 7.27 \\
\hline Transportation \& Infrastructure & 4 & 3.64 & 7 & 6.36 \\
\hline Wireless & 4 & 3.64 & 1 & 0.91 \\
\hline Total & 110 & 100 & 110 & 100 \\
\hline
\end{tabular}


Table 1- continued

Panel C: Distribution of Acquisitions by Year

\begin{tabular}{|c|c|c|}
\hline Year & No. of Observations & $\%$ of Sample \\
\hline 1994 & 1 & 0.91 \\
\hline 1995 & 1 & 0.91 \\
\hline 1996 & 1 & 0.91 \\
\hline 1997 & 3 & 2.73 \\
\hline 1998 & 1 & 0.91 \\
\hline 1999 & 1 & 0.91 \\
\hline 2000 & 4 & 3.64 \\
\hline 2001 & 4 & 3.64 \\
\hline 2002 & 3 & 2.73 \\
\hline 2003 & 1 & 0.91 \\
\hline 2004 & 1 & 0.91 \\
\hline 2005 & 5 & 4.55 \\
\hline 2006 & 3 & 2.73 \\
\hline 2007 & 6 & 5.45 \\
\hline 2008 & 8 & 7.27 \\
\hline 2009 & 9 & 8.18 \\
\hline 2010 & 10 & 9.09 \\
\hline 2011 & 19 & 17.27 \\
\hline 2012 & 16 & 14.55 \\
\hline 2013 & 13 & 11.82 \\
\hline Total & 110 & 100 \\
\hline
\end{tabular}

Forty-five (41\%) acquisitions are classified as same business based on the industry code in the SDC database. There are $72(65 \%)$ acquiring firms that have completed their first deal whereas for $38(35 \%)$ acquiring firms ${ }^{[8]}$ there is at least one deal announced and completed before the event date during the sample period. ${ }^{[9]}$

Panel B of Table 1 presents data on the distribution of industry categories in the takeover sample. As consistent with the earlier studies (Akdoğu, 2011), the most pronounced industry in the distribution is the textile industry (12\%), followed by the power industry $(10 \%)$ for acquiring firms. For target firms the most active industry is the energy power

[8] There are 72 individual acquiring firms and 110 target firms in the whole sample.

${ }^{[9]}$ If there is more than one acquisition announcement on the same day for the acquiring firm, only one is included in the sample and the deal is categorized as the first deal if it is the first deal announcement of the acquiring firm within the sample period. 
industry (16\%). Panel C of Table 1 shows the distribution of acquisitions across years. As seen from the table, there is an increasing number of acquisitions in the most recent years, especially after 2004, which is in keeping with the idea that Turkey has been experiencing a more stabilized economy in the last ten years (See Akdoğu, 2011). Consistent with the notion of growing M\&A market in Turkey, the number of acquisitions increased to a total of 90 in the last decade (2004-2013) compared to only 20 in the previous decade (1994-2003) during the sample period, an increase of more than fourfold.

\section{Cumulative Abnormal Returns}

Following the large strand of the M\&A literature I use cumulative abnormal returns (CARs) as a measure of the stock market's reaction to the deal announcement. I use conventional event study methodology (Brown and Warner, 1985) to calculate the acquirer firm CARs. The longest event window is defined as starting five days before the announcement date of the acquisition and ends five days after the announcement date. Several other event windows are computed within this large window in order to overcome the difficulty of determining the correct event window for capturing the full announcement effect. The standard event study methodology uses a market model approach.

Returns of 240 days through $300^{\text {th }}$ and $60^{\text {th }}$ days prior to the announcement date were utilized to estimate the market model parameters. Firms are included in the sample if they have at least 100 daily returns available in the estimation period. ${ }^{[10]}$ The main index of Istanbul Borsa BIST100 is used as the relevant market index $\left(\mathrm{R}_{\mathrm{m}}\right)$.

\section{Results}

\section{Univariate Analysis of Cumulative Abnormal Returns}

In Table 2, the abnormal returns measured over several event windows for the acquiring firms are reported. Panel A shows the CARs for the total sample of 106 observations where the price data is available. For the full sample, the mean and median CAR is $2.27 \%$ and $-0.22 \%$ respectively for the largest event window $[-5,+5]$. The mean and the median CAR is $0.75 \%$ and $0.17 \%$ respectively for the shortest event window [-1, $0]$. All the mean CARs for the documented event windows are statistically (mostly at the 5\% level) different from zero. The mean CARs are generally greater than the median CARs; that indicates that the means are affected by large gains in some acquisitions.

In Panel B of Table 2, the CARs of domestic and cross-border acquisitions are compared for the acquiring firms. For the $[-5,+5]$ event window, the mean CAR is $2.13 \%$ for domestic acquisitions and 3.29\% for cross-border acquisitions. On the other hand, for the event of $[-5,0]$ the mean CAR is $1.27 \%$ for the domestic acquisitions and $0.65 \%$ for cross-border acquisitions. In general, I do not observe a systematic difference between the CARs of these two groups for different event windows that is inconsistent with the

${ }^{[10]}$ If the acquiring firm announces more than one acquisition with overlapping estimation periods, the estimation period of the first announcement is used to determine the market model parameters of subsequent event windows. 
results of Oelger and Schiereck, 2011. These results indicate that the stock market does not view domestic and cross-border acquisitions differently, which is more in keeping with the findings of Moeller et al., 2011.

In Panel $\mathrm{C}$ of Table 2, the acquirer CARs are compared in the case of public targets versus private targets. ${ }^{[11]}$ The mean CAR of the acquirers that are acquiring public targets is $3.36 \%$ for the event window of $[-5,+5]$. The mean CAR is $2.13 \%$ for the private targets for the same event window. Although the mean and the median CAR for the public target group is generally higher for all event windows documented in Panel C, this difference is not statistically significant in any event window. While a significant listing effect is documented in the literature in global as well as in the U.S. markets, Turkish M\&A markets do not show any similarity to the global markets in this regard. For example, Faccioa, McConnell and Stolin (2006) show that the acquirers of listed targets earn an insignificant average abnormal return of $-0.38 \%$, while acquirers of unlisted targets earn a significant average abnormal return of $1.48 \%$ in Western Europe. While this result at first seems puzzling, we believe it is explained by the dominant payment method in the M\&A deals in Turkey. With a few exceptions, all deals are cash deals in Turkey (Arslan and Şimşir, 2015). As documented before (Chang, 1998; Yüce and Ng, 2005), there is no statistically significant difference in the wealth gains of acquirers when the payment is in cash.

The average cumulative abnormal returns of same business and unrelated acquisitions are documented in the Panel D of Table 2. The mean CAR for the same business acquisitions is $4.56 \%$ whereas it is only $0.77 \%$ for the unrelated acquisitions. The difference in mean and median CARs is statistically significant at the $1 \%$ and $5 \%$ level for the event windows $[-5,+5],[3,+3],[-1,+1],[-5,+1],[-3,+1]$. Although the difference remains persistent, it is not significant in the narrower event windows. These results suggest that acquirers earn significantly higher returns if they are acquiring a target firm within the same industry of the acquiring firm, which seem to support the idea that increased productive efficiency is received well by the market. The positive effect of business relatedness on acquirer returns in acquisitions is well documented in the literature (For example, Moeller and Schlingemann, 2005).

In Panel E of Table 2, I compare the average abnormal cumulative returns of mergers and acquisitions during the period surrounding the event announcement. In all event windows, acquirers experience significantly higher average cumulative abnormal returns in mergers compared to acquisitions. For the $[5,+5]$ event window, the average CAR is $5.57 \%$ for the mergers and only $0.57 \%$ for the acquisitions. For the event window of $[-5,0]$ the difference is similar and the mean CAR is $4.17 \%$ for the mergers and $0.32 \%$ for the acquisitions. The significant difference is persistent across means and medians of all event windows. This result is contrary to the findings documented in the extant literature. In the developed markets, it is shown that tender offers benefit acquirers significantly more than mergers around the announcement date.

\footnotetext{
${ }^{[11]}$ In this test, the private target group also includes the private subsidiaries of the acquirers. The comparison tests are also conducted for subsidiaries versus public targets. The results are qualitatively similar and therefore are omitted for brevity.
} 
Table 2

\section{Acquirer Cumulative Abnormal Returns (CARs)}

Panel A: Full Sample

\begin{tabular}{l|l|l|l|l|l|l|c}
\hline $\begin{array}{l}\text { Event } \\
\text { Window }\end{array}$ & $\mathbf{N}$ & $\begin{array}{c}\text { Mean } \\
\text { CAR }\end{array}$ & $\begin{array}{c}\text { Median } \\
\text { CAR }\end{array}$ & Min CAR & $\begin{array}{c}\text { Max } \\
\text { CAR }\end{array}$ & t-test & $\begin{array}{c}\text { Wilcoxon } \\
\text { signed-rank } \\
\text { test }\end{array}$ \\
\hline$[-5,+5]$ & 106 & $2.27 \%$ & $-0.22 \%$ & $-22.60 \%$ & $52.90 \%$ & $2.12^{* *}$ & 1.09 \\
{$[-3,+3]$} & 106 & $2.25 \%$ & $-0.06 \%$ & $-15.16 \%$ & $45.89 \%$ & $2.3 * *$ & 0.77 \\
{$[-1,+1]$} & 106 & $1.35 \%$ & $0.17 \%$ & $-11.94 \%$ & $31.66 \%$ & $2.29 * *$ & 1.38 \\
{$[-5,+1]$} & 106 & $1.79 \%$ & $0.70 \%$ & $-15.91 \%$ & $26.86 \%$ & $2.48 * *$ & $1.92 * *$ \\
{$[-3,+1]$} & 106 & $1.88 \%$ & $0.61 \%$ & $-13.35 \%$ & $28.20 \%$ & $2.68 * * *$ & $1.72 * *$ \\
{$[-5,0]$} & 106 & $1.20 \%$ & $0.11 \%$ & $-11.25 \%$ & $22.91 \%$ & $1.97 * *$ & 1.08 \\
{$[-3,0]$} & 106 & $1.29 \%$ & $0.13 \%$ & $-11.77 \%$ & $21.40 \%$ & $2.44 * *$ & 1.24 \\
\hline$-1,0]$ & 106 & $0.75 \%$ & $0.17 \%$ & $-7.77 \%$ & $15.92 \%$ & $2.16^{* *}$ & 1.28 \\
\hline
\end{tabular}

$* * *, * *$, and $*$ denote statistical significance at $1 \%, 5 \%$ and $10 \%$, respectively.

Panel B: Domestic vs. Cross-border Acquisitions

\begin{tabular}{l|c|c|c|c|c|c}
\hline \multirow{2}{*}{$\begin{array}{l}\text { Event } \\
\text { Window }\end{array}$} & \multicolumn{2}{|c|}{ Domestic N=93 } & \multicolumn{2}{c}{ Cross-border N=13 } & \multicolumn{2}{c}{ Difference Tests } \\
& Mean CAR & Median CAR & Mean CAR & Median CAR & $\begin{array}{c}\text { Mann- } \\
\text { t-test / } \\
\text { t- value }\end{array}$ & $\begin{array}{c}\text { Whitney test / } \\
\text { z-value }\end{array}$ \\
\hline$[-5,+5]$ & $2.13 \%$ & $-0.29 \%$ & $3.29 \%$ & $0.80 \%$ & -0.35 & -0.29 \\
{$[-3,+3]$} & $2.17 \%$ & $0.14 \%$ & $2.85 \%$ & $-1.73 \%$ & -0.22 & -0.81 \\
{$[-1,+1]$} & $1.37 \%$ & $0.24 \%$ & $1.16 \%$ & $0.10 \%$ & 0.12 & -0.45 \\
{$[-5,+1]$} & $1.84 \%$ & $0.89 \%$ & $1.38 \%$ & $0.43 \%$ & 0.21 & 0.51 \\
{$[-3,+1]$} & $1.92 \%$ & $0.65 \%$ & $1.67 \%$ & $0.55 \%$ & 0.12 & -0.68 \\
{$[-5,0]$} & $1.27 \%$ & $0.02 \%$ & $0.65 \%$ & $0.78 \%$ & 0.33 & -0.20 \\
{$[-3,0]$} & $1.34 \%$ & $0.17 \%$ & $0.94 \%$ & $0.08 \%$ & 0.25 & -0.32 \\
{$[-1,0]$} & $0.80 \%$ & $0.19 \%$ & $0.44 \%$ & $-0.71 \%$ & 0.33 & -0.58 \\
\hline
\end{tabular}

$* * *, * *$, and $*$ denote statistical significance at $1 \%, 5 \%$ and $10 \%$, respectively. 
Table 2- continued

Panel C: Public vs. Private Target

\begin{tabular}{l|c|c|c|c|c|c}
\hline \multirow{2}{*}{$\begin{array}{l}\text { Event } \\
\text { Window }\end{array}$} & \multicolumn{2}{|c|}{ Public N=12 } & \multicolumn{2}{c}{ Not Public N=94 } & \multicolumn{2}{c}{ Difference Tests } \\
& Mean CAR & Median CAR & Mean CAR & Median CAR & $\begin{array}{c}\text { Mann- } \\
\text { t-test / } \\
\text { t- value }\end{array}$ & $\begin{array}{c}\text { Whitney test / } \\
\text { z-value }\end{array}$ \\
\hline$[-5,+5]$ & $3.36 \%$ & $-0.29 \%$ & $2.13 \%$ & $-0.22 \%$ & 0.36 & -0.30 \\
{$[-3,+3]$} & $3.90 \%$ & $0.20 \%$ & $2.04 \%$ & $-0.06 \%$ & 0.60 & -0.04 \\
{$[-1,+1]$} & $3.22 \%$ & $0.32 \%$ & $1.11 \%$ & $0.01 \%$ & 1.14 & -0.82 \\
{$[-5,+1]$} & $3.57 \%$ & $1.60 \%$ & $1.56 \%$ & $0.66 \%$ & 0.89 & -0.61 \\
{$[-3,+1]$} & $3.62 \%$ & $2.72 \%$ & $1.66 \%$ & $0.56 \%$ & 0.88 & -0.67 \\
{$[-5,0]$} & $1.77 \%$ & $-0.24 \%$ & $1.12 \%$ & $0.20 \%$ & 0.34 & -0.14 \\
{$[-3,0]$} & $1.81 \%$ & $0.52 \%$ & $1.23 \%$ & $0.13 \%$ & 0.35 & -0.03 \\
{$[-1,0]$} & $1.41 \%$ & $0.17 \%$ & $0.67 \%$ & $0.15 \%$ & 0.67 & -0.05 \\
\hline
\end{tabular}

$* * *, * *$, and $*$ denote statistical significance at $1 \%, 5 \%$ and $10 \%$, respectively.

Panel D: Same Business vs. Unrelated Acquisitions

\begin{tabular}{l|c|c|c|c|c|c}
\hline \multirow{2}{*}{$\begin{array}{l}\text { Event } \\
\text { Window }\end{array}$} & \multicolumn{2}{|c|}{ Same business N=42 } & \multicolumn{2}{c|}{ Unrelated N=64 } & \multicolumn{2}{c}{ Difference Tests } \\
& Mean CAR & Median CAR & Mean CAR & Median CAR & $\begin{array}{c}\text { Mann- } \\
\text { t-test / } \\
\text { t- value }\end{array}$ & $\begin{array}{c}\text { Whitney test / } \\
\text { z-value }\end{array}$ \\
\hline$[-5,+5]$ & $4.56 \%$ & $1.92 \%$ & $0.77 \%$ & $-1.18 \%$ & $1.74 *$ & $-2.42 * *$ \\
{$[-3,+3]$} & $3.98 \%$ & $1.27 \%$ & $1.12 \%$ & $-0.82 \%$ & 1.44 & $-2.34 * *$ \\
{$[-1,+1]$} & $2.72 \%$ & $0.95 \%$ & $0.45 \%$ & $-0.38 \%$ & 1.92 & $-1.82 *$ \\
{$[-5,+1]$} & $3.83 \%$ & $2.33 \%$ & $0.45 \%$ & $-0.15 \%$ & $2.35 * *$ & $-2.75 * * *$ \\
{$[-3,+1]$} & $3.67 \%$ & $2.57 \%$ & $0.71 \%$ & $-0.25 \%$ & $2.09 * *$ & $-2.53 * *$ \\
{$[-5,0]$} & $2.12 \%$ & $0.73 \%$ & $0.59 \%$ & $-0.04 \%$ & 1.23 & -1.52 \\
{$[-3,0]$} & $1.96 \%$ & $0.67 \%$ & $0.85 \%$ & $-0.33 \%$ & 1.02 & -1.32 \\
{$[-1,0]$} & $1.01 \%$ & $0.35 \%$ & $0.59 \%$ & $0.14 \%$ & 0.59 & -0.17 \\
\hline
\end{tabular}

***, **, and $*$ denote statistical significance at $1 \%, 5 \%$ and $10 \%$, respectively.

Table 2- continued 
Table 2- continued

Panel E: Acquisitions vs. Mergers

\begin{tabular}{|c|c|c|c|c|c|c|}
\hline \multirow[b]{2}{*}{$\begin{array}{l}\text { Event } \\
\text { Window }\end{array}$} & \multicolumn{2}{|c|}{ Acquisition $\mathbf{N}=\mathbf{7 0}$} & \multicolumn{2}{|c|}{ Merger N=36 } & \multicolumn{2}{|c|}{ Difference Tests } \\
\hline & Mean CAR & Median CAR & Mean CAR & Median CAR & $\begin{array}{l}\text { t-test / } \\
\text { t- value }\end{array}$ & $\begin{array}{c}\text { Mann- } \\
\text { Whitney test / } \\
\text { z-value }\end{array}$ \\
\hline$[-5,+5]$ & $0.57 \%$ & $-1.30 \%$ & $5.57 \%$ & $2.74 \%$ & $-2.25 * *$ & $-2.49^{* *}$ \\
\hline$[-3,+3]$ & $0.78 \%$ & $-0.59 \%$ & $5.12 \%$ & $1.26 \%$ & $-2.13 * *$ & -1.90 \\
\hline$[-1,+1]$ & $0.73 \%$ & $0.17 \%$ & $2.53 \%$ & $0.53 \%$ & -1.46 & -0.88 \\
\hline$[-5,+1]$ & $0.33 \%$ & $0.48 \%$ & $4.62 \%$ & $2.11 \%$ & $-2.93 * * *$ & $-2.05^{* *}$ \\
\hline$[-3,+1]$ & $0.76 \%$ & $0.53 \%$ & $4.07 \%$ & $1.59 \%$ & $-2.71^{* *}$ & -1.59 \\
\hline$[-5,0]$ & $-0.32 \%$ & $-0.56 \%$ & $4.15 \%$ & $2.49 \%$ & $-3.68^{* * *}$ & $-3.11^{* * * *}$ \\
\hline$[-3,0]$ & $0.11 \%$ & $-0.60 \%$ & $3.59 \%$ & $1.44 \%$ & $-3.25 * * *$ & $-2.61^{* * *}$ \\
\hline$[-1,0]$ & $0.08 \%$ & $0.11 \%$ & $2.05 \%$ & $0.62 \%$ & $-2.75^{* *}$ & $-1.70 *$ \\
\hline
\end{tabular}

$* * *, * *$, and $*$ denote statistical significance at $1 \%, 5 \%$ and $10 \%$, respectively.

\section{Multivariate Analysis}

In this section, I examine the effect of several deal and firm characteristics on the cumulative abnormal returns of deal announcements in a multivariate setting for several event windows using the sample of 106 successful acquisitions. The regressors I include are the following: Merger is a dummy variable that is equal to one if the deal is a merger, 0 if it is the acquisition of majority interest. Domestic is a dummy variable if the target firm is a Turkish company, 0 if the target is an international company. Public target is a dummy variable that is equal to 1 if the target is listed in a stock exchange, 0 if it is not listed. The same business is equal to 1 if the acquirer and target firms are in the same industry defined by the SDC database, 0 otherwise. These are the variables that are considered in the univariate tests as potential sources of acquirer abnormal returns.

As control variables, I also include factors found to be correlated with acquirers' announcement period returns in other studies. Deal experience is a dummy variable that is equal to 1 if the acquirer has completed another acquisition deal in the sample period and it is 0 if the deal is the acquirer's first deal. The percentage acquired is the percentage of ownership acquired by the acquirer ${ }^{[12]}$ Acquirer Size is the log of market capitalization of the acquirer firm measured one day prior to the event window. The dependent variable in the regressions is the CAR for the acquiring firm for the event windows $[-5,+5]$ and $[-5,0] .{ }^{[13]}$ All the continuous variables are winsorized at the $1 \%$ level. The correlation matrix of all independent variables is presented in Table 3.

\footnotetext{
${ }^{[12]}$ This variable is set to $100 \%$ for the mergers.

${ }^{[13]}$ The results are qualitatively similar for other event windows used in this study. To preserve space, the results are reported for only event windows $[-5,+5]$ and $[-5,0]$.
} 
Table 3

Correlation Matrix

\begin{tabular}{|c|c|c|c|c|c|c|c|}
\hline & Merger & $\begin{array}{c}\% \\
\text { acquired }\end{array}$ & Domestic & $\begin{array}{l}\text { Public } \\
\text { Target }\end{array}$ & $\begin{array}{c}\text { Same } \\
\text { Business }\end{array}$ & $\begin{array}{c}\text { Deal } \\
\text { Experience }\end{array}$ & $\begin{array}{c}\text { Acquirer } \\
\text { Size }\end{array}$ \\
\hline Merger & 1 & & & & & & \\
\hline$\%$ acquired & 0.3829 & 1 & & & & & \\
\hline Domestic & 0.0291 & 0.1446 & 1 & & & & \\
\hline Public Target & 0.0301 & -0.2121 & 0.0468 & 1 & & & \\
\hline $\begin{array}{l}\text { Same } \\
\text { Business }\end{array}$ & 0.0601 & -0.018 & -0.0391 & 0.0963 & 1 & & \\
\hline $\begin{array}{l}\text { Deal } \\
\text { Experience }\end{array}$ & 0.2061 & -0.0887 & -0.0894 & -0.0291 & 0.0954 & 1 & \\
\hline Acquirer Size & 0.0222 & 0.1285 & -0.1004 & 0.0946 & 0.077 & 0.2971 & 1 \\
\hline
\end{tabular}

Firms with multiple acquisitions may learn from prior experiences and this learning should benefit the strategists in the acquiring company. (Very and Schweiger, 2001; Hayward, 2002). Therefore, I expect a positive relationship between the acquirer returns and the experienced acquirer dummy variable. It is well shown in the M\&A literature that smaller acquirers earn higher abnormal returns around announcement day. For example see Moeller et al. (2004) report that small acquirers earn 2\% higher cumulative abnormal returns on the announcement of the acquisition compared to large acquirers (See also Loderer and Martin, 1990; Faccio et al., 2006; Schwert, 2000).

The results are documented in Table 4 . The dependent variable is the CAR for the acquirer for the event window $[-5,+5]$ in models 1 to 4 and it is the CAR for the event window $[-5,0]$ in models 5 to 8 . Since the merger dummy and the percentage acquired have a high correlation (0.3829), I include these variables separately and then together in models. The coefficient merger dummy is positively significant at the $1 \%$ or $5 \%$ level wherever it is included except in model 4 . The coefficient of the percentage acquired is positively significant at the $5 \%$ level in models 3 and 7 , where merger dummy is excluded. The coefficient of Same Business dummy is positive and significant only in models for the event window $[-5,+5]$. Consistent with the earlier findings of univariate analysis, domestic dummy and public target dummy do not seem to affect the CARs of acquirer firms. The size of the acquiring firm is negative and significant only in models 3 and 4 , consistent with the findings in the literature.

Taken all together, the results in the multivariate analysis provide further evidence for the findings presented in the univariate analysis. 
Table 4

Multivariate analyses of acquirer returns

\begin{tabular}{|c|c|c|c|c|c|c|c|c|}
\hline \multirow{2}{*}{$\begin{array}{l}\text { Dependent } \\
\text { Variable } \\
\text { Regressor }\end{array}$} & \multicolumn{4}{|c|}{$\operatorname{CAR}[-5,+5]$} & \multicolumn{4}{|c|}{ CAR $[-5,0]$} \\
\hline & 1 & 2 & 3 & 4 & 5 & 6 & 7 & 8 \\
\hline \multirow[t]{2}{*}{ Merger } & $0.038^{* *}$ & $0.034 * *$ & & 0.025 & $0.031^{* * *}$ & $0.031 * * *$ & & $0.027 * *$ \\
\hline & $(2.58)$ & (2.29) & & (1.49) & (3.35) & (3.29) & & $(2.57)$ \\
\hline \multirow[t]{2}{*}{ Domestic } & 0.012 & 0.011 & 0.005 & 0.006 & 0.006 & 0.015 & 0.011 & 0.013 \\
\hline & $(0.56)$ & $(0.51)$ & $(0.21)$ & $(0.28)$ & $(0.41)$ & $(1.06)$ & $(0.76)$ & $(0.90)$ \\
\hline \multirow[t]{2}{*}{ Public Target } & 0.012 & 0.008 & 0.013 & 0.013 & 0.002 & 0.014 & 0.016 & 0.016 \\
\hline & $(0.56)$ & $(0.34)$ & $(0.53)$ & $(0.53)$ & $(0.16)$ & $(0.92)$ & (1.01) & $(1.03)$ \\
\hline \multirow[t]{2}{*}{$\begin{array}{l}\text { Same } \\
\text { business }\end{array}$} & $0.033 * *$ & $0.027^{*}$ & $0.024 *$ & $0.026^{*}$ & 0.013 & 0.01 & 0.008 & 0.009 \\
\hline & $(2.38)$ & (1.91) & (1.69) & $(1.81)$ & $(1.40)$ & (1.11) & $(0.82)$ & $(1.05)$ \\
\hline \multirow{2}{*}{$\begin{array}{l}\text { Deal } \\
\text { Experience }\end{array}$} & 0.004 & 0.011 & 0.008 & 0.012 & -0.001 & -0.002 & -0.005 & -0.001 \\
\hline & $(0.28)$ & $(0.71)$ & $(0.55)$ & $(0.76)$ & $(-0.07)$ & $(-0.17)$ & $(-0.50)$ & $(-0.14)$ \\
\hline \multirow[t]{2}{*}{$\%$ acquired } & & & $0.001^{* *}$ & 0.000 & & & $0.001^{* *}$ & 0.000 \\
\hline & & & (2.13) & $(1.24)$ & & & $(2.12)$ & $(0.79)$ \\
\hline \multirow[t]{2}{*}{ Acquirer Size } & & -0.007 & $-0.008^{*}$ & $-0.008^{*}$ & & -0.004 & -0.004 & -0.004 \\
\hline & & $(-1.56)$ & $(-1.73)$ & $(-1.75)$ & & $(-1.23)$ & $(-1.29)$ & $(-1.34)$ \\
\hline \multirow[t]{2}{*}{ Constant } & -0.022 & 0.113 & 0.098 & 0.105 & -0.012 & 0.048 & 0.037 & 0.044 \\
\hline & $(-0.99)$ & $(1.26)$ & (1.08) & $(1.17)$ & $(-0.81)$ & $(0.84)$ & $(0.63)$ & $(0.78)$ \\
\hline Adjusted $R^{2}$ & 0.069 & 0.044 & 0.037 & 0.050 & 0.075 & 0.090 & 0.030 & 0.086 \\
\hline $\begin{array}{l}\text { No of } \\
\text { Observations }\end{array}$ & 106 & 98 & 98 & 98 & 106 & 98 & 98 & 98 \\
\hline
\end{tabular}

The t-stastics are in parantheses. ${ }^{* * *}, * *$, and $*$ denote statistical significance at $1 \%, 5 \%$ and $10 \%$, respectively.

\section{Conclusion}

This study investigates the short term wealth effects of mergers and acquisitions for the acquiring company shareholders in Turkey over the period 1994-2013. Contrary to the findings in U.S. and European markets, the acquirers in Turkey earn a significant positive CAR of $2.27 \%$ during an 11-day announcement period. In addition, the study shows that the wealth increase is significantly greater in mergers than in acquisitions. Within-industry acquisitions are also found to create higher abnormal returns for the acquirer shareholders compared to diversifying acquisitions which is in keeping with the findings in the M\&A literature. 
However, the study does not find any statistically significant evidence that crossborder acquisitions or a target's public status have any impact on the announcement period abnormal returns of the acquirer. These findings prevail in cross-sectional regressions in which acquisition announcement returns are the dependent variable and are robust to the inclusion of several control variables such as the size of acquirer, whether the acquirer is experienced in M\&As and the percentage of shares acquired in the target company.

\section{References}

Agrawal, A., Jaffe, J.F., and Mandelker, G.N. (1992). "The Post-merger Performance of Acquiring Firms: A Re-examination of an Anomaly," Journal of Finance, 47: 1605-1622.

Akben-Selçuk, E. (2008). "The Impact of Cross-border Mon Target Company Performance: Evidence from Turkey," Economics Bulletin, 13/5: 13: 1-9.

Akdoğu, E. (2011). "Mergers, Acquisitions and Merger Waves in Turkey during the Years of 19882008," Journal of Accounting and Finance, 52: 137-152.

Akdoğu, E. (2012). "The foreign and domestic acquirer profiles in the 2005-2008 merger wave," Journal of Accounting and Finance, 55: 51-70.

Ang, J.S. and Cheng, Y. (2006). "Direct Evidence on the Market-driven Acquisitions Theory," Journal of Financial Research, 29(2): 199-216.

Arslan, H.B. and Şimşir, S.A. (2015). "Measuring Takeover Premiums in Cross-Border Mergers and Acquisitions: Insights from Turkey," Emerging Markets Finance and Trade, forthcoming.

Asquith, P., Bruner, R.F., and Mullins, D.W. (1987). "Merger Returns and the Form of Financing," Working paper, University of Virginia.

Aybar,B. and Fiçıc1, A. (2009). "Cross-Border Acquisitions and Firm Value: An Analysis of EmergingMarket Multinationals,” Journal of International Business Studies, 40(8): 1317- 1338.

Betton, S., Eckbo, B.E., and Thorburn, K.S. (2009). "Merger Negotiations and the Toehold Puzzle," Journal of Financial Economics, 91: 158-178.

Bhagat, S., Malhotrab, S., and Zhu, P. (2011). "Emerging Country Cross-border Acquisitions: Characteristics, Acquirer Returns and Cross-sectional Determinants," Emerging Markets Review, 12: 251-271.

Bradley, M.A., Desai, A., and Kim, E.H. (1988). "Synergistic Gains from Corporate Acquisitions and Their Division between Stockholders of Target and Acquiring Firms," Journal of Financial Economics, 21: 3-40.

Bradley, M. and Sundaram, A. (2006). "Acquisitions and Performance: a Re-assessment of the Evidence," Working Paper. Duke University.

Brown, S.J. and Warner, J.B. (1985). "Using Daily Stock Returns," Journal of Financial Economics, 14:B3-31.

Bruner, R. (2004). "Where M\&A Pays and Where It Strays: A Survey of the Research," Journal of Applied Corporate Finance, 16(4): 63-76.

Capron, L. and Shen, J. (2007). "Acquisitions of Private vs. Public Firms: Private İnformation, Target Selection, and Acquirer Returns," Strategic Management Journal, 28: 891-911.

Chang, S. (1998). "Takeovers of Privately Held Targets, Method of Payment, and Bidder Returns," Journal of Finance, 52: 773-784. 
Chari, A., Ouimet, P.P. and Tesar, L.L. (2009). "The value of control in emerging markets," Review of Financial Studies, 23: 1741-1770.

Chatterjee, R. and Aw, M. (2000). "The Performance of UK Firms Acquiring Large Cross-border and Domestic Takeover Targets," Judge Institute of Management Studies Research Paper WP07/00, Cambridge, UK.

Chi, J., Sun, Q., and Young, M. (2011). "Performance and Characteristics of Acquiring Firms in the Chinese Stock Markets," Emerging Markets Review 12(2) June: 152-170.

Conn, R.L., Cosh, A., Guest P.M., and Hughes, A. (2005). "The Impact on UK Acquirers of Domestic, Cross-border, Public and Private Acquisitions," Journal of Business Finance \& Accounting, 32(5): 815-870

Çukur, S., and Eryiğit, R. (2006). "Stock Market Reaction to Bank Merger \& Acquisitions," Iktisat, İşletme ve Finans Dergisi, 21: 96-107.

Datta, S., Iskandar-Datta, M., and Raman, K. (2001). "Executive Compensation and Corporate Acquisition Decisions," Journal of Finance, 56(6): 2299-2336.

Dos Santos, M.B., Errunza, V., and Miller, D. (2008). "Does Corporate International Diversification Destroy Value? Evidence from Cross-border Mergers and Acquisitions," Journal of Banking \& Finance, 32: 2716-2724.

Eckbo, B.E. (2009). "Bidding Strategies and Takeover Premiums: A Review," Journal of Corporate Finance, 15:149-178.

Eckbo, B.E. and Thorburn, K.S. (2000). "Gains to Bidder Revisited: Domestic and Foreign Acquisitions in Canada," Journal of Financial and Quantitative Analysis 35(1): 1-25.

Erdoğan, A.I. (2012). "The Determinants of Mergers and Acquisitions: Evidence from Turkey," International Journal of Economics and Finance, 4(4): 72-77.

Faccio, M., McConnell, J.J., and Stolin, D. (2006). "Returns to Acquirers of Listed and Unlisted Targets," Journal of Financial and Quantitative Analysis, 41(01): 197-220.

Fee, C.E. and Thomas, S. (2004). "Sources of gains in horizontal mergers: Evidence from customer, supplier, and rival firms," Journal of Financial Economics, 74: 423-460.

Fuller, K., Netter, J., and Stegemoller, M. (2002). "What Do Returns to Acquiring Firms Tell Us? Evidence from Firms that Make Many Acquisitions," Journal of Finance, 57: 1763-94.

Goergen, M. and Renneboog, L (2004). Shareholder Wealth Effects of European Domestic and Crossborder Takeover Bids," European Financial Management, 10(1): 9-45.

Hayward, M.L.A. (2002). "When Do Firms Learn from Their Acquisition Experience? Experience from 1990-1995," Strategic Management Journal, 23: 21-39.

Hekimoğlu, M.H. and Tanyeri, B. (2011). "Stock Market Reactions to Mergers of Non-financial Turkish Firms,” İktisat, İşletme, ve Finans, 26(308): 53-70.

Jensen, M.C. and Ruback, R.S. (1983). "The Market for Corporate Control, the Scientific Evidence," Journal of Financial Economics, 11: 5-0.

Kohli, R. and Mann, B.J.S. (2012). "Analyzing Determinants of Value Creation in Domestic and Cross Border Acquisitions in India," International Business Review, 21: 998-1016.

Lang, L., Stulz, R.M., and Walkling, R.A. (1989). "Managerial Performance, Tobin's $Q$ and the Gains from Successful Tender Offers,” Journal of Financial Economics, 24: 137-154. 
Loderer, C. and Martin, K. (1990). "Corporate Acquisitions by Listed Firms: The Experience of Comprehensive Sample," Financial Management, 19: 17-33.

Loughran, T. and Vijh, A.M. (1997). "Do Long-Term Shareholders Benefit from Corporate Acquisitions?" Journal of Finance, 52(5): 1765-1790.

Ma, J., Pagán, J.A., and Chu, Y. (2009). "Abnormal Returns to Mergers and Acquisitions in Ten Asian Stock Markets," International Journal of Business, 14(3): 235-250.

Mandacı, P.E. (2004). "The Effect of Merger and Acquisition Announcements on Stock Prices," İktisat, İsletme ve Finans Dergisi, 19(225): 118-124.

Mandac1, P.E. (2005). "The Effects of Mergers and Acquisitions on the Financial Structure and Performance of the Firms," Iktisat, İsletme ve Finans Dergisi, 20(233): 60-67.

Martynova, M. and Renneboog, L. (2008). "A Century of Corporate Takeovers: What have We Learned and where Do We Stand?," Journal of Banking \& Finance, 32: 2148-2177.

Moeller, S.B. and Schlingemann, F.P. (2005). "Global Diversification and Bidder Gains: A Comparison between Cross-border and Domestic Acquisitions," Journal of Banking \& Finance, 29: 533-564.

Moeller, S.B., Schlingemann, F.P., and Stulz, R.M. (2004). "Firm Size and the Gains from Acquisitions," Journal of Financial Economics, 73: 201-228.

-----, (2005). "Wealth Destruction on a Massive Scale? A Study of Acquiring Firm Returns in the Recent Merger Wave," Journal of Finance 60: 757-782.

-----, (2007). "How do Diversity of Opinion and Information Asymmetry Affect Acquirer Returns?" Review of Financial Studies, 20: 2047-2078.

Mumcu, A. and Zenginobuz, U. (2005). "An Analysis of Mergers and Acquisitions in the Turkish Banking Sector," Research in the Middle East Economics, 6: 133-162.

Netter, J., Stegemoller, M., and Wintoki, M.B. (2011). "Implications of Data Screens on Merger and Acquisition Analysis: A Large Sample Study of Mergers and Acquisitions from 1992 to 2009," Review of Financial Studies, 24:2316-2357.

Oelger, M., and Schiereck, M. (2011). "Cross-border M\&A and International Stock Market Integration - Evidence from Turkey," International Journal of Economics Research, 2: 40-55.

Seth, A., Song, K.P., and Pettit, R.R. (2002). "Value Creation and Destruction in Cross-Border Acquisitions: An Empirical Analysis of Foreign Acquisitions of U.S. Firms," Strategic Management Journal, 23: 921-940.

Shahrur, H. (2005). "Industry Structure and Horizontal Takeovers: Analysis of Wealth Effects on Rivals, Suppliers, and Corporate Customers," Journal of Financial Economics, 76: 61-98.

Shimizu, K., Hitt, M.A., Vaidyanath, D., and Pisano, V. (2004). "Theoretical Foundations of Crossborder Mergers and Acquisitions: A Review of Current Research and Recommendations for the Future," Journal of International Management, 10: 307-353.

Schwert, G.W. (2000). "Hostility in Takeovers: In the Eye of Beholder?" Journal of Finance, 55: 2599-2640.

Sudarsanam, S. and Mahate, A.A. (2003). "Glamour Acquirers, Method of Payment and Post-Acquisition Performance: The UK Evidence,” Journal of Business Finance \& Accounting, 30 (1/2): 299-341.

Travlos, N.G. (1987). "Corporate Takeover Bids, Methods of Payment, and Bidding Firms' Stock Returns," Journal of Finance, 42(4): 943-963. 
Very, P. and Schweiger, D.M. (2001). "The Acquisition Process as a Learning Process: Evidence from a Study of Critical Problems and Solutions in Domestic and Cross-border Deals," Journal of World Business, 36 (1): 11-31.

Yüce, A. and Ng, A. (2005). "Effects of Private and Public Canadian Mergers," Canadian Journal of Administrative Sciences, June: 111-124. 